\title{
GROWTH AND DISPERSAL OF A SOUTHEAST AFRICAN LARGE IGNEOUS PROVINCE
}

\author{
K. GOHL \\ Alfred Wegener Institute for Polar and Marine Research, Department of Geosciences, Am Alten Hafen \\ 26, D-27568 Bremerhaven, Germany \\ e-mail: karsten.gohl@awi.de
}

G. UENZELMANN-NEBEN

Alfred Wegener Institute for Polar and Marine Research, Department of Geosciences, Am Alten Hafen 26, D-27568 Bremerhaven, Germany

e-mail: gabriele.uenzelmann-neben@awi.de

\section{N. GROBYS}

RWE Dea AG, Überseering 40, D-22297 Hamburg, Germany; formerly: Alfred Wegener Institute for Polar and Marine Research, Germany

e-mail: nicole.grobys@rwe.com

(C) 2011 December Geological Society of South Africa

\begin{abstract}
The Mozambique Ridge (MOZR) and the Agulhas Plateau (AP) are prominent bathymetrically elevated rises off south-eastern Africa connected by a rise of less bathymetric expression. Intuitively, this observation would imply that the plateaus and rises underwent a related crustal formation. Deep crustal ocean-bottom seismometer data and a multichannel seismic reflection profile from the southern MOZR show evidence for its predominantly oceanic crustal origin with excessive volcanic eruption and magmatic accretion phases. The lower two-thirds of the crustal column exhibit P-wave velocities of more than $7.0 \mathrm{~km} / \mathrm{s}$, increasing to 7.5 to $7.6 \mathrm{~km} / \mathrm{s}$ at the crustal base. These velocities suggest that the lower crust was accreted by large volumes of mantle-derived material to form an over-thickened equivalent of an oceanic layer 3. The velocity-depth model and the seismic reflection data of the MOZR resemble those of the AP, which suggests that a greater Southeast African Large Igneous Province (LIP) must have formed between 140 and $95 \mathrm{Ma}$ in phases of highly varying magmatic and volcanic activities. The timing, size, and formation history of the Southeast African LIP is similar to those of the Kerguelen-Heard Plateau, which invites speculation about related processes of episodic magma generation at that time.
\end{abstract}

\section{Introduction}

The Cretaceous was characterised by several almost synchronous massive volcanic events, which accreted voluminous magmatic material to the crust. The mantle processes, causing the formation of such Large Igneous Provinces (LIP), are partially understood (e.g. Torsvik et al., 2006). Attempts have been made to correlate such events to phases of rapid global warming during the 'greenhouse' world and to mass extinction (Courtillot, 1999). The Kerguelen Plateau and the Ontong-Java Plateau are the two major oceanic LIPs which were active in the Cretaceous (Eldholm and Coffin, 2000). This study concerns geophysical evidence for a third synchronous LIP in the offshore region of southeastern Africa, with the Mozambique Plateau (MOZR) and the Agulhas Plateau (AP) as its main constituents.

These submarine plateau and ridge are prominent features in the Indian Ocean off south-eastern Africa (Figure 1). In the west, the Agulhas Plateau is morphologically isolated from the continent by the Agulhas Passage. East of it, the Mozambique Ridge has a morphological connection to the African continent. The AP and MOZR are separated by the Transkei Basin and a corridor of oceanic crust which is bathymetrically shallower by about 500 to $1000 \mathrm{~m}$ than the surrounding Indian Ocean crust at $5000 \mathrm{~m}$ water depth, and also shallower by a few hundred meters than the seafloor of the Transkei Basin (Figure 1). The fact that this corridor of shallower water and/or thicker crust, which we name Transkei Rise (TR), cannot be dated by magnetic spreading anomalies can be used to argue that its age falls within the magnetically quiet Cretaceous period (120 to $80 \mathrm{Ma}$ ). Various authors have discussed the crustal origin and nature of the AP and the MOZR (e.g., Ben-Avraham et al., 1995; Gohl and UenzelmannNeben, 2001; Marks and Tikku, 2001; König and Jokat, 2006, 2010; Parsiegla et al., 2008). However, the concept of a potential common evolutionary history of both features has not been taken into account. Gohl and Uenzelmann-Neben (2001) and Parsiegla et al. (2008; 2009) found geophysical evidence for the AP to be regarded an oceanic Large Igneous Province (LIP), consisting of over-thickened oceanic crust formed at 110 to $95 \mathrm{Ma}$. Small continental fragments, which may explain the few dredged rock samples of felsic composition (Tucholke et al., 1981, Ben-Avraham et al., 


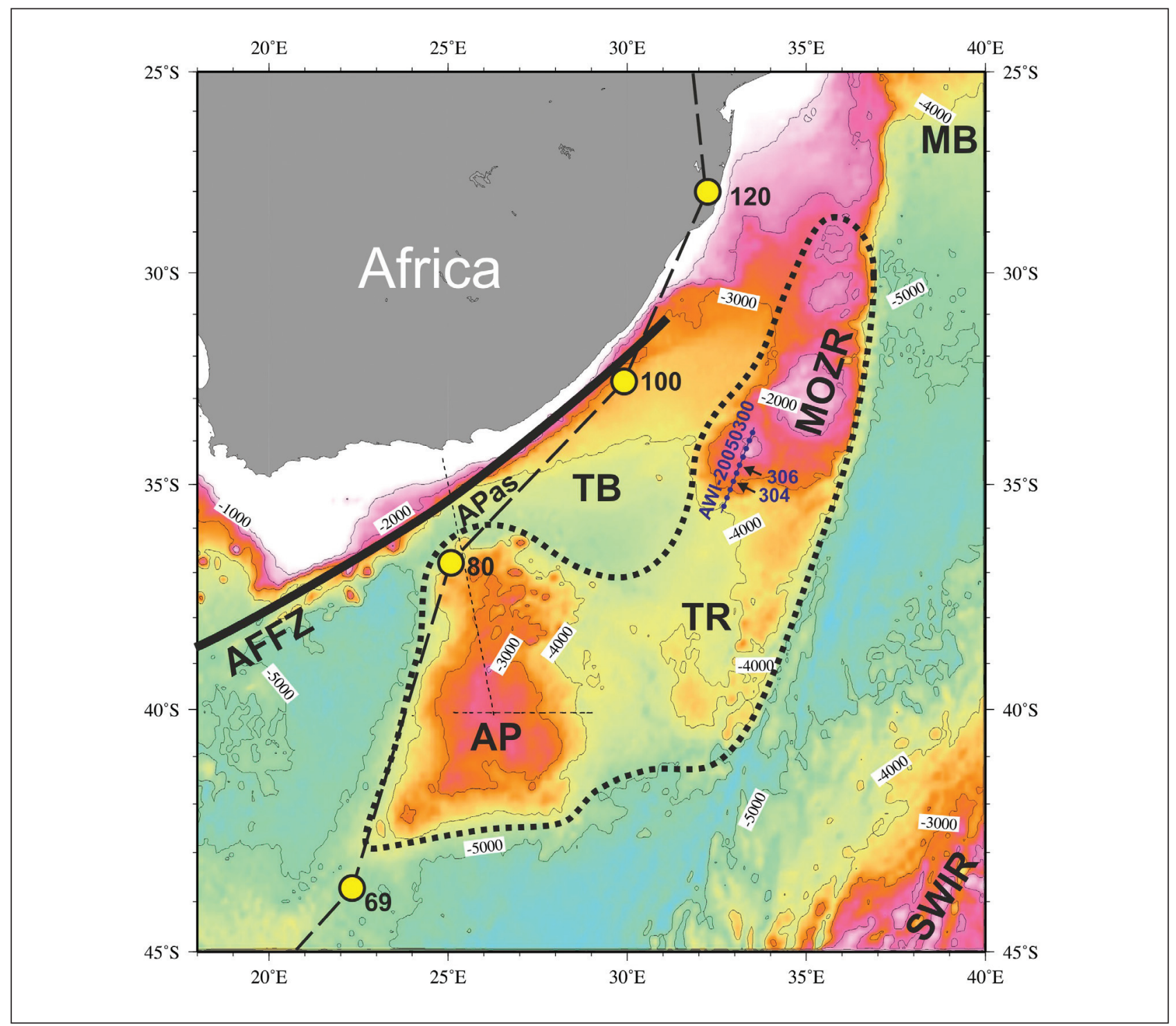

Figure 1. Submarine plateaus and ridges in the southwestern Indian Ocean illustrated on a satellite-derived bathymetry map (Smith and Sandwell, 1997) with locations of the deep crustal seismic profile AWI-20050300 across the southwestern Mozambique Ridge (MOZR) shown in this paper and related deep crustal seismic profiles across the Agulhas Plateau (AP) by Gohl and Uenzelmann-Neben (2001) and Parsiegla et al. (2008) (thin dashed lines). Indicated are the two OBS stations from which data are shown in Figure 2. The thick dotted line surrounds magmatic provinces we interpret to belong to the same southeastern African large igneous province event. The dashed line with yellow dots marks the Bouvet hotspot track with ages in million years (Hartnady and le Roex, 1985; Martin, 1987). AFFZ Agulhas-Falkland Fracture Zone, APas Agulhas Passage, TB Transkei Basin, TR Transkei Rise (name used in this paper), MB Mozambique Basin, SWIR Southwest Indian Ridge.

1995), cannot be entirely excluded. Previous geoscientific studies of the MOZR (e.g., Ben-Avraham et al., 1995) failed to reveal its deep crustal nature and origin. Some scattered dredged rock samples (BenAvraham et al., 1995) imply a continental affinity of the MOZR. Although plate-kinematic studies adopted a continental MOZR and placed the MOZR adjacent to the Astrid Ridge of Dronning Maud Land in Antarctica (Marks and Tikku, 2001; König and Jokat, 2006), a continental block of substantial size, as the entire MOZR would be, does not allow a close fit in the pre-breakup position of Africa and Antarctica. König and Jokat (2010) analysed new densely-spaced magnetic survey data across the MOZR and the Mozambique Basin and excluded the presence of major continental blocks throughout the MOZR.

We collected deep crustal seismic data, using oceanbottom seismometers (OBS), and multichannel seismic (MCS) reflection data from the southern MOZR as part of a larger research program during RV Sonne cruise SO-182 (Schlüter and Uenzelmann-Neben, 2008; Parsiegla et al., 2008; 2009) (profiles and OBS stations in Figure 1). The data analyses provide new evidence for the structure and composition of the MOZR and are compared with geophysical models of the AP. 

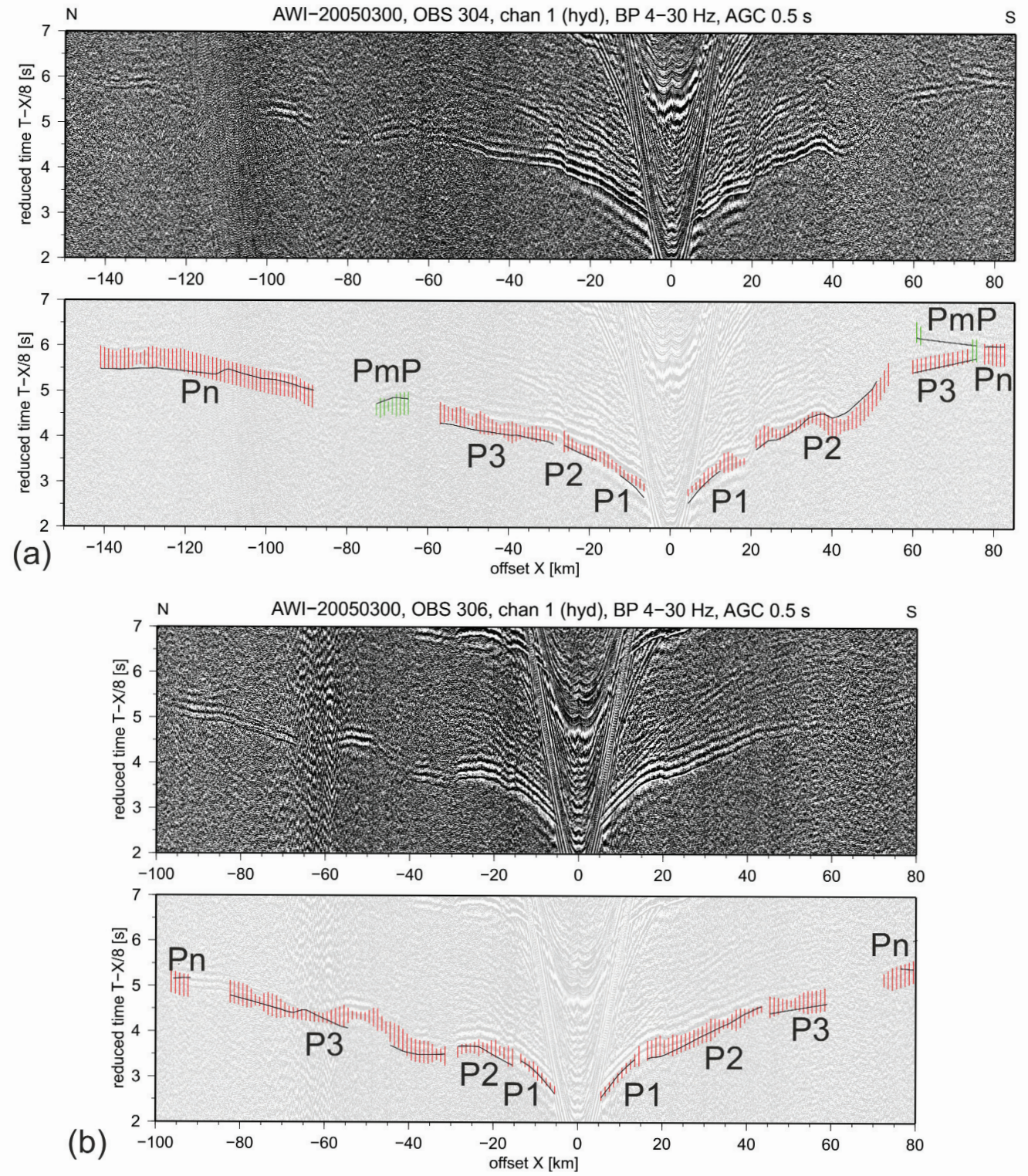

Figure 2. Examples of ocean-bottom seismometer (OBS) records of profile AWI-20050300 with identified P-wave refraction arrival phases from the upper crust to the top of lower crust $\left(P_{1}\right.$ to $\left.P_{3}\right)$, reflection phases from the crust-mantle boundary $\left(P_{m} P\right)$, and refracted phases from the uppermost mantle $\left(P_{n}\right)$. The top figures of station $304(\boldsymbol{a})$ and station $306(\boldsymbol{b})$ show the data records, the bottom figures illustrate the observed phase picks (vertical bars show uncertainty range) and modeled travel-times (black lines).

\section{Overthickened oceanic crust observed from deep crustal data}

For OBS system description, airgun sources as well as seismic refraction and MCS acquisition and processing parameters of the data collected during the SO-182 cruise, we refer to Schlüter and Uenzelmann-Neben (2008) and Parsiegla et al. (2008; 2009). Of the ten OBS systems deployed along the $240 \mathrm{~km}$ long profile AWI20050300, eight systems recorded good-quality and useful data. Most records show P-wave arrivals on hydrophone and vertical component channels of up to
$150 \mathrm{~km}$ offset. Observed P-wave arrival phases include refracted arrivals from the upper crust to the top of lower crust, mid-crustal wide-angle reflections, mediumamplitude reflection phases from the crust-mantle boundary, and some refracted phases from the uppermost mantle (example in Figure 2). Large-offset S-wave phases are only observed from 2 to 3 stations and could not be used for modelling.

We applied a standard 2-D ray-tracing and traveltime inversion technique (Zelt and Smith, 1992) to derive a crustal velocity-depth model from the identified 


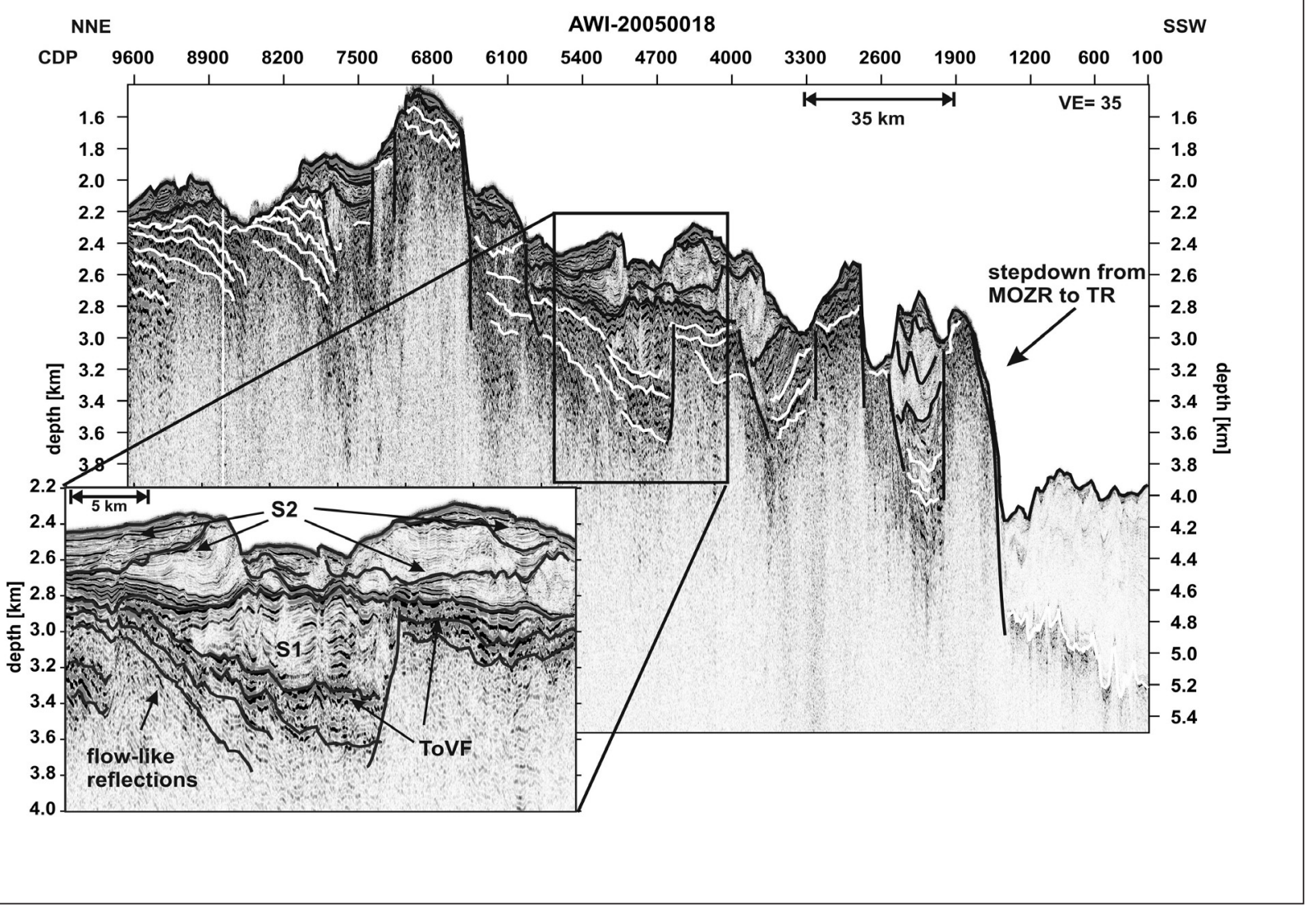

Figure 3. Seismic reflection profile AWI-20050018 (coincident to AWI-20050300). White lines show top of basement and intra-basement reflections. ToVF top of interpreted volcanic flows, S1 lower sedimentary unit, S2 upper sedimentary unit, MOZR Mozambique Ridge, TR Transkei Rise.

P-wave travel-times. The top of acoustic basement and sedimentary structures were constrained from the MCS data (Figure 3). The overall rms-misfit between observed and calculated travel-times of $0.194 \mathrm{~s}$ and a $\chi^{2}$ of 1.57 demonstrate a reasonable fit of the data to the model parameters. Despite the relatively short profile and the lack of usable data from two of the ten stations, the ray-coverage and model resolution allow the characterization of all crustal layers and the crust-mantle boundary along a representative length across the southern MOZR.

The crustal velocity-depth model (Figure 4), derived from the OBS data, shows a crustal thickness of 20 to $22 \mathrm{~km}$ in the central part of the profile. The crust thins in its southernmost part, which coincides with a major down-step in basement depth to the south from a range of 2.0 to $3.5 \mathrm{~km}$ to about 4.5 to $5.0 \mathrm{~km}$ below seafloor (b.s.f.). The lateral velocity distribution within the mid to lower crust appears to be rather homogeneous, an observation which is accompanied by the lack of any intra-crustal wide-angle reflections in the OBS data. Taking the lower crust as the unit with P-wave velocities from 7.0 to $7.5 \mathrm{~km} / \mathrm{s}$, which are distinctively higher than those of the middle crust of 5.5 to $6.5 \mathrm{~km} / \mathrm{s}$, then lower crust constitutes two-thirds of the crustal column. The mid to lower crustal velocity discontinuity remains at the same $10 \mathrm{~km}$ depth-line b.s.f. southward across the basement and Moho down-steps. Acoustic basement and upper crustal velocities increase from 3.5 to $5.5 \mathrm{~km} / \mathrm{s}$ with lateral variations at top of basement from $4.5 \mathrm{~km} / \mathrm{s}$ in lower-lying areas covered with sediments to $3.5 \mathrm{~km} / \mathrm{s}$ in areas where basement penetrates the sedimentary cover.

The vertical and horizontal velocity distribution and crustal thickness of this part of the southern MOZR we surveyed is analogue to those observed for the AP (Gohl and Uenzelmann-Neben, 2001; Parsiegla et al., 2008). Both the AP and the MOZR are characterised by overthickened, seismically homogeneous, lower crustal units making up between half to two-thirds of the crustal column with P-wave velocities of more than $7.0 \mathrm{~km} / \mathrm{s}$ and increasing to 7.4 to $7.6 \mathrm{~km} / \mathrm{s}$ at the crustal base (Figure 4). These very high velocities imply that the lower crust was thickened by the addition of large volumes of mantle-derived magma. Large quantities of uprising hot peridotitic melts can be generated by adiabatic decompression. Trumbull et al. (2002) have shown for the Namibian volcanic margin that mantle 
temperatures of 1450 to $1560^{\circ} \mathrm{C}$ can generate basaltic melts of 14 to $18 \% \mathrm{MgO}$ content which results in P-wave velocities between 7.25 and $7.4 \mathrm{~km} / \mathrm{s}$. A similar relationship can be expected for the lower crust of the MOZR.

\section{Evidence for strong magmatism in multi-channel seismic data}

The MCS data show no continuous sedimentary cover on the southern MOZR (Figure 3). We observe a thickness of the sedimentary column between 20 and $1100 \mathrm{~m}$ in two sedimentary units. The unit below sedimentary unit S1 is characterized by short, low frequency reflections, which are inclined. They can be followed for 20 to $35 \mathrm{~km}$ and form sub-parallel stratified wedges, which in places overlap (Figure 3, CDPs 7800 to 9600 , white reflections). This unit is topped by a hummocky reflection, which we interpret as the top of basement. Faults with a ?vertical displacement of up to $700 \mathrm{~m}$ cut through both basement and the sedimentary units. A step-down in basement of $2 \mathrm{~km}$ is observed in the south and defines the boundary of the MOZR to the Transkei Rise.

The wedges of inclined reflectors resemble seaward dipping reflectors (SDR) associated with volcanic passive margins and flood basalt volcanic fields (e.g. Hinz, 1981; Franke et al., 2007). Similar structures have been observed on the AP where they were interpreted as volcanic flows emerging from extrusion centres (Gohl and Uenzelmann-Neben, 2001; Parsiegla et al., 2008). In contrast to the AP, we do not observe extrusion centres on the southern MOZR. Furthermore, with the exception of the structures observed between CDPs 2700 and 3600 (Figure 3), which probably is an effect of faulting and thus rotation of this block, the flow-like reflections are inclined southwards. Interpreting the flow-like reflections as SDRs implies that the seafloor spreading centre creating those features must have been active in the south.

Seismic data from the Astrid Ridge, the conjugate structure at the Antarctic continental margin, clearly show northward dipping SDR wedges (Hinz et al., 2004). They form a $\sim 75 \mathrm{~km}$ wide zone with individual reflections which can be traced for up to $20 \mathrm{~km}$. This strongly resembles our observation from the southern MOZR. We hence suggest that the SDR wedges observed at both the southern MOZR and the Astrid Ridge were formed during the separation of the two structures, implying that both plateaus formed as a single structural unit and share the same LIP formation process.

Following the formation of SDRs, the southern MOZR was subject to faulting (Figure 3, CDPs 1500, 4600, and 7800), which may be considered as evidence for the extension during the separation from the Astrid Ridge and AP. In this, the southern MOZR resembles the AP (Parsiegla et al., 2008) where volcanic flows and faults bear witness to extrusive volcanism followed by extension during the fragmentation of the larger LIP into

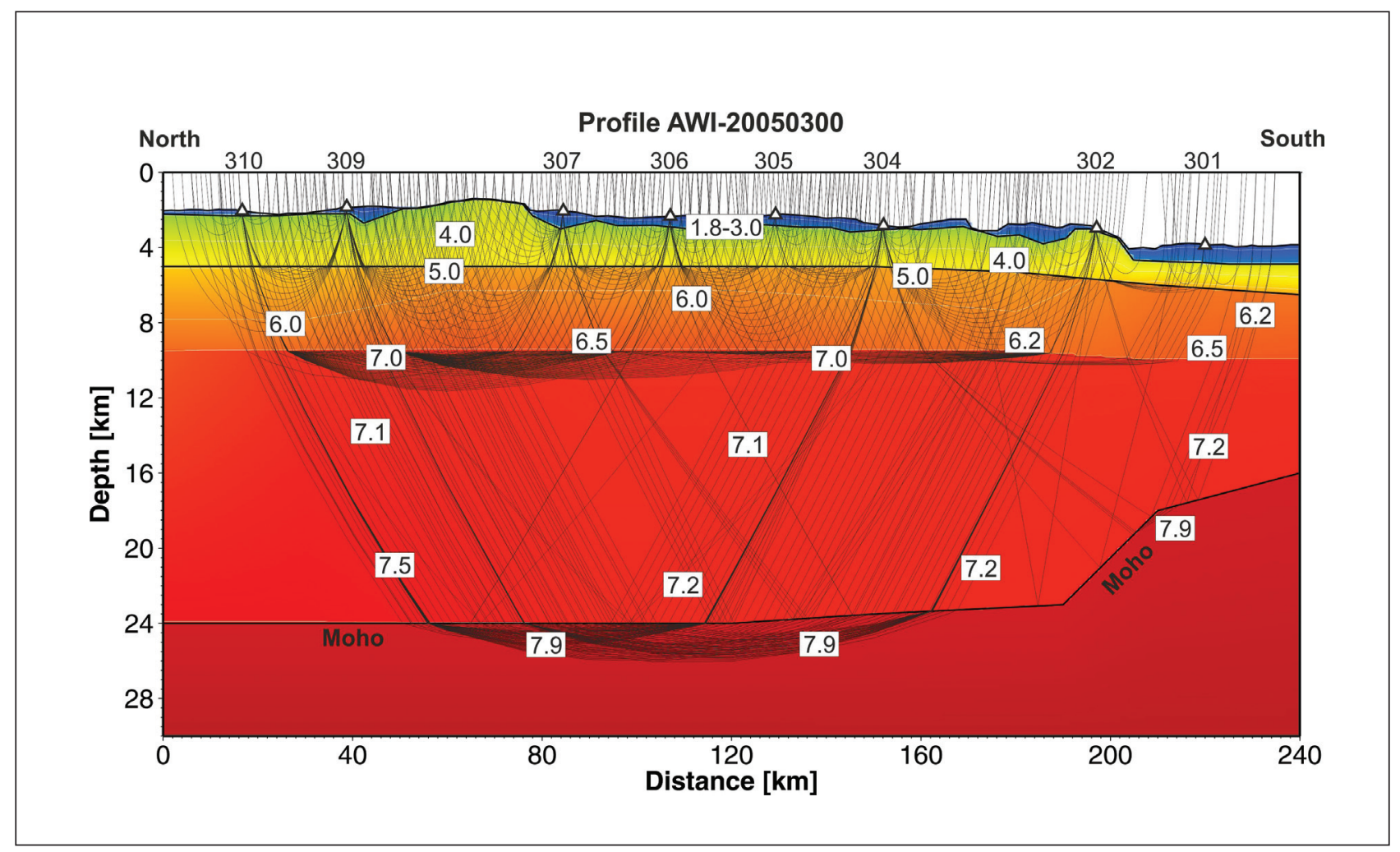

Figure 4. P-wave velocity-depth distribution model of profile AWI-20050300 with ray coverage of the travel-time inversion and OBS locations (station numbers and triangles). Velocities are in $\mathrm{km} / \mathrm{s}$. 

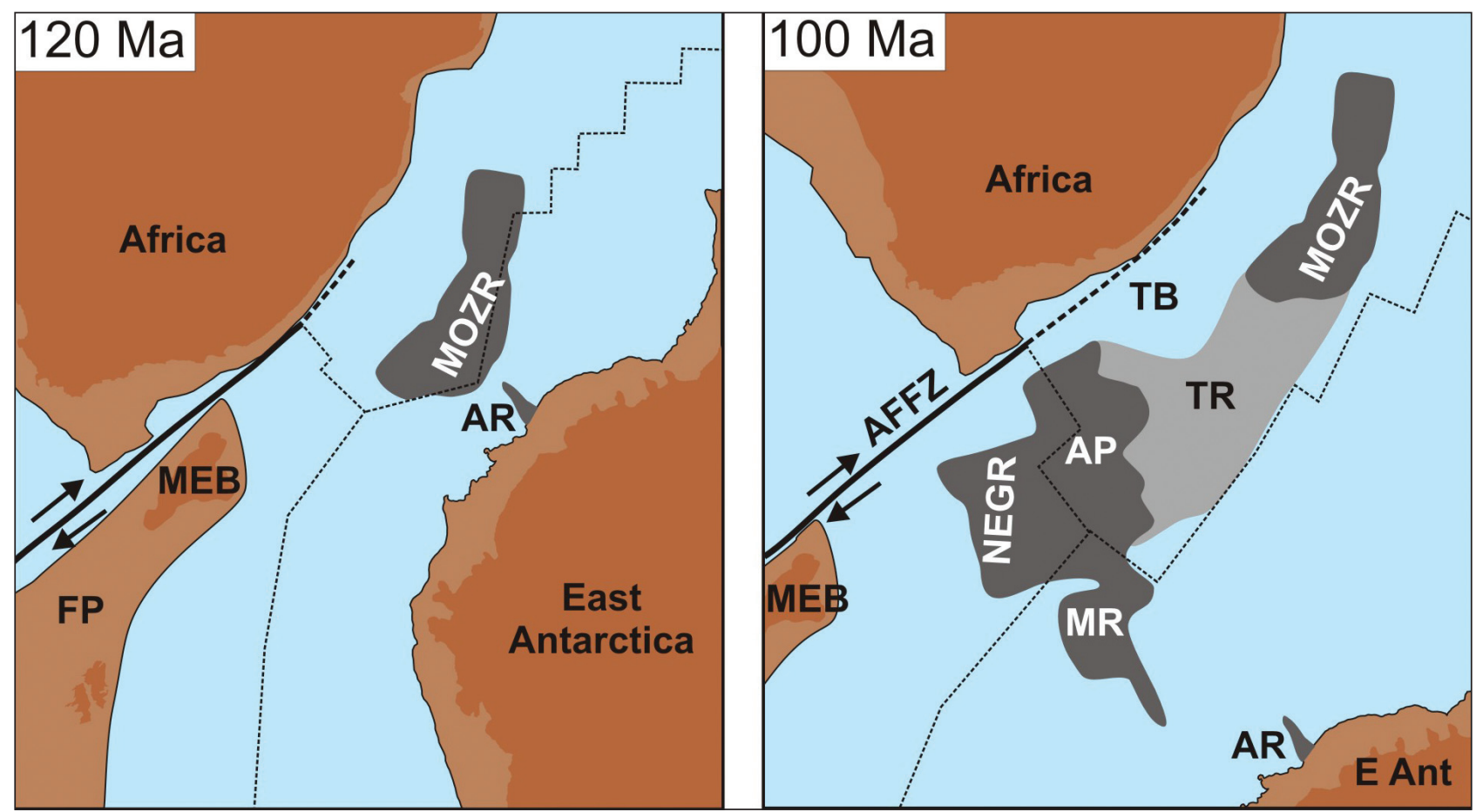

Figure 5. Reconstruction model for formation of the southeast African LIP between 120 and 100 Ma. Dark grey areas of Mozambique Ridge (MOZR), Agulhas Plateau (AP), North-East Georgia Rise (NEGR), Maud Rise (MR) and the northern Astrid Ridge (AR) are fully developed oceanic plateau LIPs, while Transkei Rise (TR) is a partially developed LIP province. AFFZ Agulhas-Falkland Fracture Zone, TB Transkei Basin, FP Falkland Plateau, MEB Maurice Ewing Bank, E Ant East Antarctica.

separate fragments consisting of the present-day AP, the Northeast Georgia Rise off the Falkland Plateau, and Maud Rise off East Antarctica (Figure 5).

A second phase of tectonism affected the MOZR after sedimentation of unit S1 draped the morphology of the first tectonic phase, resulting in faults affecting the whole sedimentary column up to seafloor at CDPs 2000, 2400, 2700, 3900, 4600, 5900, 6500, 7100, and 7400 (Figure 3). Sediments deposited after the tectonic event indicate the onset of current-controlled sedimentation as the result of intensified North Atlantic Deep Water in Pliocene times (Schlüter and Uenzelmann-Neben, 2008; Uenzelmann-Neben et al., 2011). This indicates that the later tectonic event took place in the Pliocene. Ben Avraham et al. (1995) speculated on neotectonic activity on the MOZR. They interpret their observations as a result of uplift related to the African Superswell.

\section{Timing and extent of Large Igneous Province formation}

The plate-kinematic reconstructions provide relative constraints for the timing of formation of the LIP components off southeastern Africa. In most recent reconstructions (e.g. by Marks and Tikku, 2001; König and Jokat, 2006), the MOZR was treated as a continental microplate which had an independent motion between M11 and M2 (133 to 124 Ma) (Marks and Tikku, 2001) and which was located in close vicinity of an extinct spreading center. König and Jokat (2010) present new magnetic data from the MOZR and the Mozambique
Basin to its northeast, which indicate a volcanic formation of the rise between 140 and 122 Ma. In our model (Figure 5), for which the rotation parameters of König and Jokat $(2006 ; 2010)$ are applied, the MOZR must have reached its own maximum extent by about $120 \mathrm{Ma}$ while the Antarctic-African spreading zone ran beneath its eastern flank. Parts of the Astrid Ridge were possibly attached and developed as part of the same magmatic process. The main volcanic formation of the greater AP together with the Northeast Georgia Rise (NEGR) and Maud Rise (MR) can be estimated to be around $100 \mathrm{Ma}$ (Gohl and Uenzelmann-Neben, 2001; Parsiegla et al., 2008) when the region in the vicinity of the triple junction passed over the Bouvet hotspot. This main eruption phase lasted to about $94 \mathrm{Ma}$ (Parsiegla et al., 2008), after which the NEGR and MR detached from the AP by continued regular seafloor spreading.

Both the plateau and rise are connected by the Transkei Rise, a crustal corridor at $4500-3500 \mathrm{~m}$ water depth (Figures 1 and 3). We can rule out thicker sedimentary cover because it has the same 1.5 to $1.7 \mathrm{~km}$ thickness just to the southwest of the MOZR as observed for the lower lying Transkei Basin (Schlüter and Uenzelmann-Neben, 2008). If normal oceanic spreading with normal oceanic thickness had occurred south and southwest of the MOZR in the Early Cretaceous, the seafloor would have subsided to a mean depth of around $5000 \mathrm{~m}$, similar to the crust surrounding the MOZR-TR-AP province to the east, south, and west. 
We, therefore, infer a slightly over-thickened crystalline crust for the Transkei Rise. It is reasonable to assume that there had been a continuous process of excess volcanic activity in the $\sim 20 \mathrm{Ma}$ period between the main formation of the MOZR and that of the greater AP. The similarity of the crustal structure and seismic velocity-depth distribution between the MOZR and AP is striking and suggests that they developed in the same magmatic regime which produced accreted mantlederived magmas of similar Mg-rich composition. The distinctly thinner Transkei Rise, however, implies that active LIP magmatism continued between the main formation of the MOZR and that of the greater AP but with much less intensity.

Before AP-NEGR-MR separation, this Southeast African LIP (Figure 5) comprised a total area of approximately $1.2 \times 10^{6} \mathrm{~km}^{2}$ of oceanic plateau formation which is comparable in size to that of the greater Kerguelen-Heard Plateau LIP in the southern Indian Ocean. The Kerguelen-Heard Plateau had its major formation phase at about the same time and exhibits - at least for its northern plateau - a similar proportional seismic velocity depth distribution (Charvis et al., 1995; Gohl and Uenzelmann-Neben, 2001). It also developed in phases of varying magmatic eruption intensity with its main accreted volumes in its northern and southern plateau while the central plateau remained relatively thin (Gladczenko and Coffin, 2001). This observation invites speculation that both LIP formations in the developing Indian Ocean may have been related by repeated processes of magma generation.

\section{Conclusions}

Analyses of OBS data and an MCS profile from the southern MOZR are compared with geophysical models of the AP and provide evidence for the formation of a greater Southeast African LIP. The velocity-depth distribution of the MOZR shows that the both the MOZR and the AP consist of lower crustal units making up between half to two-thirds of the crustal column with P-wave velocities of more than $7.0 \mathrm{~km} / \mathrm{s}$, increasing to 7.5 to $7.6 \mathrm{~km} / \mathrm{s}$ at the crustal base. These velocities imply that the lower crust was accreted by large volumes of mantle-derived material to form an over-thickened equivalent of an oceanic layer 3. Similar to the AP, the southern MOZR must therefore be of predominantly oceanic origin.

The MCS data reveal SDR sequences similar to those observed on the AP and Astrid Ridge. The southern MOZR resembles the AP. There, volcanic flows and faults bear witness to extrusive volcanism followed by extension during the fragmentation of the larger LIP into its provinces AP, NEGR, and MR. On the MOZR, we only observe faults as a document of the separation of MOZR and Astrid Ridge. This may be an indication for modifications in magma supply.

The MOZR and AP are connected by a bathymetrically elevated corridor, the Transkei Rise, which implies a continuous process of less extensive volcanic activity in the $\sim 20$ Ma period between the main formation of the MOZR and that of the greater AP. A similarity can be observed between the timing, size and formation history of the Southeast African LIP and the Kerguelen-Heard Plateau, which provokes speculation about related processes of periodic magma generation at that time.

\section{Acknowledgements}

Our access to the OBS systems of IFM-GEOMAR through E. Flüh and J. Bialas is gratefully acknowledged. This study is part of project AISTEK-I which was funded by the German Bundesministerium für Bildung und Forschung under BMBF contract no. 03G0182A. This study is part of the German - South African cooperative project Inkaba yeAfrica with publication number 47 .

\section{References}

Ben-Avraham, Z., Hartnady, C.J.H. and le Roex, A.P., 1995. Neotectonic activity on continental fragments in the southwest Indian Ocean: Agulhas Plateau and Mozambique Ridge, Journal of Geophysical Research, 100, 6199-6211.

Charvis, P., Recq, M., Operto, S. and Brefort, D., 1995. Deep structure of the northern Kerguelen Plateau and hotspot-related activity, Geophysical Journal International, 122, 899-924.

Courtillot, V., 1999. Evolutionary Catastrophes: The Science of Mass Extinction, Cambridge University Press, New York, U.S.A., 188pp.

Eldholm, O. and Coffin, M.F. (2000). Large igneous provinces and plate tectonics, In: M. Richards, R. Gordon and R. van der Hilst (Editors). The history and dynamics of global plate motions, American Geophysical Union, Geophysical Monograph 121, 309-326.

Franke, D., Neben, S., Ladage, S., Schreckenberger, B. and Hinz, K., 2007. Margin segmentation and volcano-tectonic architecture along the volcanic margin off Argentina/Uruguay, South Atlantic, Marine Geology, 244, 46-67.

Gladczenko, T.B. and Coffin, M.F., 2001. Kerguelen Plateau crustal structure and basin formation from seismic and gravity data, Journal of Geophysical Research, 106, 16583-16601

Gohl, K. and Uenzelmann-Neben, G., 2001. The crustal role of the Agulhas Plateau, southwest Indian Ocean: evidence from seismic profiling, Geophysical Journal International, 144, 632-646.

Hartnady, C.J.H. and le Roex, A.P., 1985. Southern Ocean hotspot tracks and the Cenozoic absolute motion of the African, Antarctic, and South American plates, Earth and Planetary Science Letters, 75, 245-257.

Hinz, K., 1981. A hypothesis on terrestrial catastrophes: Wedges of very thick oceanward dipping layers beneath the passive continental margins - Their origin and paleoenvironmental significance, Geologisches Jahrbuch, E22, 3-28.

Hinz, K., Neben, S., Gouseva, Y.B. and Kudryavtsev, G.A., 2004. A compilation of geophysical data from the Lazarev Sea and the RiiserLarsen Sea, Antarctica, Marine Geophysical Research, 25, 233-245, doi:10.1007/s11001-005-1319-y

König, M. and Jokat, W., 2006. The Mesozoic breakup of the Weddell Sea, Journal of Geophysical Research, 111, doi:10.1029/2005JB004035.

König, M. and Jokat, W., 2010. Advanced insights into magmatism and volcanism of the Mozambique Ridge and Mozambique Basin in the view of new potential field data, Geophysical Journal International, 180, 158-180, doi:10.1111/j.1365-246X.2009.04433.x.

Marks, K.M. and Tikku, A.A., 2001. Cretaceous reconstructions of East Antarctica, Africa and Madagascar, Earth and Planetary Science Letters, 186, 479-495.

Martin, A.K., 1987. Plate reorganisations around Southern Africa, hot spots and extinctions, Tectonophysics, 142, 309-316.

Parsiegla, N., Gohl, K. and Uenzelmann-Neben, G., 2008. The Agulhas Plateau: Structure and evolution of a Large Igneous Province, 
Geophysical Journal International, 174, 336-350, doi:10.1111/j.1365246X.2008.03808.x.

Parsiegla, N., Stankiewicz, J., Gohl, K., Ryberg, T. and Uenzelmann-Neben, G., 2009. Southern African continental margin: dynamic processes of a transform margin, Geochemistry Geophysics Geosystems, 10, doi:10.1029/2008GC002196.

Schlüter, P. and Uenzelmann-Neben, G., 2008. Indications for bottom current activity since Eocene times: The climate and ocean gateway archive of the Transkei Basin, South Africa, Global and Planetary Change, 60, 416-428, doi:10.1016/j.gloplacha.2007.07.002

Smith, W.H.F. and Sandwell, D.T., 1997. Global sea floor topography from satellite altimetry and ship depth sounding, Science, 277, 1956-1962.

Torsvik, T.H., Smethurst, M.A., Burke, K. and Steinberger, B., 2006. Large igneous provinces generated from the margins of the large low-velocity provinces in the deep mantle, Geophysical Journal International, $167,1447-1460$.

Trumbull, R.B., Sobolev, S.V. and Bauer, K., 2002. Petrophysical modeling of high seismic velocity crust at the Namibian volcanic margin. In: M.A
Menzies, S.L. Klemperer, C.J. Ebinger and J Baker, J. (Editors), Volcanic Rifted Margins, Geological Sopciety of America Special Paper, 362, 221-230

Tucholke, B.E., Houtz, R.E. and Barrett, D.M., 1981. Continental crust beneath the Agulhas Plateau, southwest Indian Ocean, Journal of Geophysical Research, 86, 3791-3806.

Uenzelmann-Neben, G., Watkeys, M.K., Kretzinger, W., Frank, M. and Heuer, 1., 2011. Palaeoceanographic Interpretation of a seismic profile from the southern Mozambique Ridge, Southwestern Indian Ocean, South African Journal of Geology, 114, 449-458. doi:10.2113/gssajg.114.3-4.449.

White, R.S. and McKenzie, D.P. (1989). Magmatism at rift zones: the generation of volcanic continental margins and flood basalts, Journal of Geophysical Research, 94, 7685-7729.

Zelt, C.A. and Smith, R.B., 1992. Seismic traveltime inversion for 2-D crustal velocity structure, Geophysical Journal International, 108, 16-34.

Editorial handling: R.B. Trumbull 